\title{
DEVELOPING A COST EFFECTIVE ENVIRONMENTAL SOLUTION FOR PRODUCED WATER AND CREATING A NEW WATER RESOURCE
}

\author{
Quarterly Technical Report \\ Reporting Period: October 1, 1996 - December31, 1996 \\ Author: Glenn Doran \\ Report Issue Date: January, 1997 \\ DE-FC22-95MT95008
}

\begin{abstract}
ARCO Western Energy 4550 California Ave.
\end{abstract}

Bakersfield, CA 93302 


\section{DISCLAIMER}

This report was prepared as an account of work sponsored by an agency of the United States Government. Neither the United States Government nor any agency thereof, nor any of their employees, makes any warranty, express or implied, or assumes any legal liability or responsibility for the accuracy, completeness, or usefulness of any information, apparatus, product, or process disclosed, or represents that its use would not infringe privately owned rights. Reference herein to any specific commercial product, process, or service by trade name, trademark, manufacturer, or otherwise does not necessarily constitute or imply its endorsement, recommendation, or favoring by the United States Government or any agency thereof. The views and opinions of authors expressed herein do not necessarily state or reflect those of the United States Government or any agency thereof. 


\begin{abstract}
This report summarizes the status of this project for the quarter October 1, 1996 to December 31, 1996. Phase I has been completed and Phase II will start in the first quarter of 1997. A membrane process treatment train has been selected for the pilot study and the estimated treated water cost is 21-27 cents per barrel for a 42,000 barrel per day full scale treatment plant. The pilot study will provide information to refine the design and cost estimate. The project is slightly behind schedule. A no cost extension is being requested. The anticipated completion date is December 31, 1997 rather than the current June 24, 1997. The project is on budget.
\end{abstract}




\section{TABLE OF CONTENTS}

SECTION

EXECUTIVE SUMMARY

INTRODUCTION

RESULTS AND DISCUSSION

CONCLUSIONS
PAGE

i

1

1

3

TOC-1 


\section{PRODUCED WATER, A "NEW" DRINKING WATER RESOURCE DRAFT QUARTERLY TECHNICAL PROGRESS REPORT FOR THE QUARTER OCTOBER 1, 1996 TO DECEMBER 31, 1996}

\section{EXECUTIVE SUMMARY}

Produced water from the Placertia Oil Field in California shall be used for the study. If this project is successful, a commercial scale treatment plant may be built for the Santa Clarita Valley, California. The following was performed in Phase I: analyze current and anticipated state and Federal regulations, perform a detailed literature search of water treatment technologies to meet these regulations, and test at bench scale promising technologies. Phase I has been completed. Phase II will involve the following: construct and operate a pilot plant to collect water quality and operational data, and transfer this technology. Phase II will start in the first quarter of 1997.

The key produced water quality issues are total dissolved solids (6,000-10,000 mg/L), organics associated with oil (Oil and Grease $\sim 50 \mathrm{mg} / \mathrm{L}$ and Total Organic Carbon $120 \mathrm{mg} / \mathrm{L}$ ), ammonia - N ( 15 mg/L), borate ( 66 mg/L), water temperature ( 170 F), and disinfection byproducts.

The literature review indicated that a membrane based treatment train ( reverse osmosis (RO)) had a lower capital and operating cost than a thermal based technology (mechanical vapor compression (VC)). The planning level estimates for a full scale 42,000 barrel per day product water capacity plant for capital were \$11 million and \$27 million for the RO and VC, respectively. On an annual cost basis with operations and maintenance the estimated costs were 21-27 and 70 cents per barrel, respectively. VC does not remove ammonia and has a 90 percent removal for organics. The thermal based technology has to have processes to remove these parameters which increased the capital and operational cost.

The bench scale work determined that the hot precipitation process provides no additional advantage over warm precipitation in terms of silica removal. The optimal removal for silica and boron occurred when magnesium was added and the $\mathrm{pH}$ was adjustment to 9.5-9.7. Residual silica and boron concentrations at this $\mathrm{pH}$ was between 5-10 ppm. Residual hardness at these conditions ranged from 100-150 ppm total hardness. The bench scale studies indicated that enhanced softening did not remove additional organics.

The tentative pilot process train includes the following:

- Precipitative soften at $\mathrm{pH}$ 9.5-10.0 to remove some hardness and boron and most of the silica,

- Heat exchange cooling and $\mathrm{pH}$ reduction,

- Fixed film biological oxidation of organics and ammonia removal using a trickling filter,

- Filtration,

- lon exchange softening to remove residual hardness,

- Reverse osmosis at $\mathrm{pH}$ 8.0-11.0,

- Water stabilization for internal corrosion control,

- Disinfection to obtain residual.

The project team is pulling together the necessary equipment to assemble the pilot plant. It is anticipated that the pilot scale activities will start in February-March 1997. 


\section{INTRODUCTION}

This quarterly progress report is an update of each task.

\section{RESULTS AND DISCUSSION}

Phase I has been completed and a draft Phase I Summary Technical Report is being submitted under separate cover. The project is in the early portion of Phase II, Task 7.

\section{Phase I - Literature review and bench scale studies}

\section{Task 1A: Organize a technical review committee.}

This task is 100 percent compete and was described in the previous quarterly report.

Task 1B: Manage the Technical Review Panel

This task is 95 percent complete for Phase 1.

A Technical Review Panel was held on September 25, 1996 in Newport Beach, California. This was an initial briefing meeting to review the scope of the project and the proposed treatment train for the pilot scale studies. In the upcoming quarter, there is one activity left before it will be 100 percent completed for Phase 1. An information packet is being sent to the Technical Review Panel for their review and comment. This work should be completed by the end of the first quarter in 1997.

\section{Task 2: Literature Review}

This task is 100 percent complete and summarized in the Phase 1 Technical Summary Report. The literature review indicated that a membrane based process was the best technical approach. The thermal processes still require treatment for ammonia (no removal) and organics (90 percent removal). When adding these additional processes in addition to a thermal based process such as vapor compression, a planning level cost estimate indicated that the membrane based processes even with extensive pretreatment, was lower with respect to capital and operations and maintenance costs. The estimated water treatment cost is $21-27$ cents per barrel.

\section{Task 3: Formulate Alternatives}

This task is 100 percent completed. The proposed treatment process is the following:

- Precipitative soften at $\mathrm{pH}$ 9.5-10.0 to remove some hardness and boron and most of the silica (residual expected: 100-200 ppm Hardness, 5-10 ppm silica, and 5-10 ppm boron)

- Heat exchange cooling and $\mathrm{pH}$ reduction so they do not interfere with the biological process,

- Fixed film biological oxidation of organics and ammonia removal using a trickling filter,

- Filtration,

- Ion exchange softening to remove residual hardness,

- Reverse osmosis at $\mathrm{pH}$ 8.0-11.0, 
- Water stabilization for internal corrosion control,

- Disinfection to obtain residual.

\section{Task 4: Work Plan for Bench Scale Studies}

This task is 100 percent completed. The work plan focused on precipitive softening and is included as Appendix B of the Draft Topical Phase I Technical Summary Report.

\section{Task 5: Perform Bench Scale Studies}

This task is 100 percent completed. These results are summarized in the Phase 1 Technical Summary Report. In brief, a pH of 9.5-9.8 with magnesium at 160-170 ${ }^{\circ} \mathrm{F}$ was the most effective condition to remove hardness, silica, and boron. The total organic carbon (TOC) did not change with varying softening regimes of lime and caustic so it does not appear that enhanced softening occurs with these waters.

\section{Task 6: Literature and Bench Scale Report}

Approximately 100 percent of this task has been completed. The Draft Topical Phase I Technical Summary Report is being submitted to DOE under separate cover.

\section{Task 10A: Technology Transfer}

Several abstracts are being submitted for presentations at professional meeting of the Phase I activity and are listed below.

1) Developing a New Water Resource from Oil Field Produced Water Water Resources '97, AWWA Sponsored Specialty Conference Seattle, Washington

August 10-13, 1997

Corresponding Author: Darrell Fruth

2) Evaluation of Technologies to Treat Oil Field Produced Water to Drinking Water or Reuse Quality

Society of Petroleum Engineers Annual Conference

San Antonio, TX

October 6-8, 1997

Corresponding Author: Glenn Doran

3) Simultaneous Removal of Silica and Boron from Produced Water by Chemical Precipitation 1997 International Water Conference, Engineer's Society of Western Pennsylvania

Pittsburgh, PA

November 3-5, 1997

Corresponding Author: Joseph A. Drago 


\section{Phase II-Pilot Scale Studies}

\section{Task 1C: Manage Technical Review Panel}

Scheduled to start in the first quarter of 1997. There is a meeting planned in the first quarter of 1997 to be followed by a meeting in the third quarter just prior to finalizing the draft final project report.

\section{Task 7: Develop Pilot Scale Test Work Plan}

The work for this task has been scheduled to start in January 1997 and will be completed before the start of the pilot study. The plan will identify the treatment processes, the anticipated operating conditions, sampling points, and parameters to be monitored. The Technical Review Committee, Technical Review Panel, California Department of Health Services, and the California EPA, Regional Water Quality Control Board, Los Angeles Region will review and comment on the work plan.

\section{Task 8: Perform Pilot Scale Test Studies}

This work is scheduled to start in March 1997, the of first quarter of 1997. We expect that the pilot plant studies to start on schedule

\section{Task 9: Pilot Scale Test Study Summary and Final Report}

This work is scheduled to start in the third quarter of 1997 . We are currently on schedule with this activity.

\section{Task 10B: Technology Transfer, Phase II Activities}

This work is scheduled to start in the second and third quarter of 1997. Meetings and journals will be identified at this time. Appropriate abstracts will be developed to meet the requirements of the meetings. It is anticipated that the presentations could then be turned into an appropriate publishable paper.

\section{SCHEDULE}

A project schedule is attached. It indicates that the project completion is estimated to be in November 1997. The current project completion date is June 24, 1997. A no cost extension is being requested under separate cover.

\section{CONCLUSIONS}

A membrane technology has been selected for the Phase II pilot study. The estimated cost for water treatment is 21-27 cents per barrel. Three abstracts are being submitted for presentation at professional meetings for technology transfer. The project is slightly behind on schedule. A no cost extension is being requested. Phase I has been completed and Phase II of the project will start in the first quarter of 1997. The anticipated completion date is December 31, 1997 rather than the current June 24, 1997. The project is on budget. 


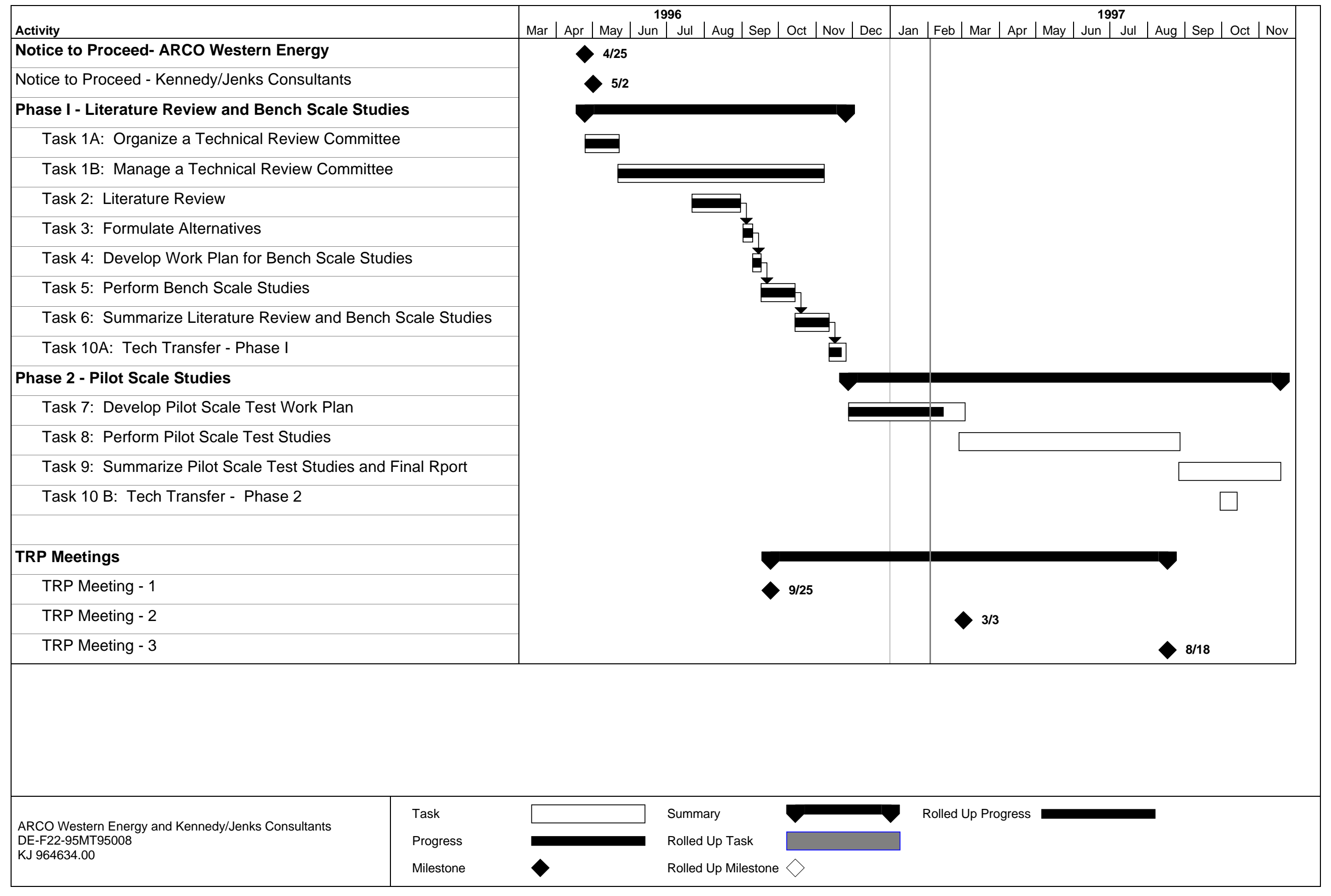

